\title{
THYROGLOBULIN IN FINE-NEEDLE ASPIRATION WASHOUT DIAGNOSTIC PERFORMANCE: A META-ANALYSIS
}

\section{SAPIENZA \\ Giorgio Grani and Angela Fumarola \\ UNIVERSITA DI ROMA \\ Dept. of Experimental Medicine - Endocrinology Unit - Sapienza University of Rome}

\section{BACKGROUND}

Differentiated thyroid cancer (DTC) has an excellent prognosis. However, DTC frequently metastasizes to cervical lymph nodes (CLN). In case of suspicious ultrasonographic findings, the fine-needle aspiration (FNA) is usually required to confirm or exclude metastasis. The combination of FNA-cytology and thyroglobulin (Tg) measurements in the needle washout has been reported to increase the sensitivity of FNA in identifying lymph node metastases from DTC, particularly in the case of very small CLN. This assay is recommended by the revised American Thyroid Association guidelines for the follow-up of patients with DTC.

\section{METHODS}

We have selected, through electronic databases, 28 original studies, published from 1992 to 2012. Each study deals with a small number of patients and is likely affected by selection bias. Pooled sensitivity, specificity, likelihood ratios (LR) and diagnostic odds ratio (dOR) were calculated.

\section{RESULTS}

Processing all the studies with complete data (17 studies), the following results have been achieved: pooled sensitivity $95.8 \%$ (95\% CI $94.3-97 \%)$, specificity 91.5\% (95\% CI 89.1-93.5\%), positive LR 15.33 (95\% CI 6.97-33.70), and negative LR $0.06(95 \%$ CI $0.04-0.11)$. However, there is a significant heterogeneity between studies, not due to threshold effect (Spearman correlation coefficient $-0.146 ; p=0.52$ ). A meta-regression analysis demonstrated that the presence or absence of thyroid gland (evaluation before thyroidectomy or during after-surgery follow-up) is an important heterogeneity factor (rdOR 4.57; 95\% CI 1.34-15.61; $p=0.02)$. Processing the data from patients during follow-up (10 studies, Figure 1), it resulted that the pooled sensitivity is $98.7 \%$ (95\% CI $96.8 \%$ 99.7\%), specificity 97.9\% (95\% CI 95.2-99.3\%), positive LR 17.47 (95\% CI 7.81-39.10), and negative LR 0.04 (95\% CI $0.02-0.09)$

\section{CONCLUSION}

FNA-Tg measurement is a very accurate tool to detect CLN metastases from DTC. However, a better standardization of criteria for patient selection, analytical methods and threshold levels is required to provide useful data and to improve management of DTC patients.

\section{STUDIES INCLUDED IN THE ANALYSIS}

Boi F, Baghino G, Atzeni F, Lai ML, Faa G \& Mariotti S. The diagnostic value for differentiated thyroid carcinoma metastases of thyroglobulin $(\mathrm{Tg})$ measurement in washout fluid from fine-needle aspiration biopsy of neck lymph nodes is maintained in the presence of circulating anti-Tg antibodies. J Clin Endocrinol Metab 200691 1364-1369.

Bournaud C, Charrie A, Nozieres C, Chikh K, Lapras V, Denier ML, Paulin C, Decaussin-Petrucci M Peix JL, Lifante JC, Cornu C, Giraud C, Orgiazzi J \& Borson-Chazot F. Thyroglobulin measurement in fineneedle aspirates of lymph nodes in patients with differentiated thyroid cancer: a simple definition of the threshold value, with emphasis on potential pitfalls of the method. Clin Chem Lab Med 201048 1171-1177.

Cignarelli M, Ambrosi A, Marino A, Lamacchia O, Campo M, Picca G \& Giorgino F. Diagnostic utility of thyroglobulin detection in fine-needle aspiration of cervical cystic metastatic lymph nodes from papillary thyroid cancer with negative cytology. Thyroid 200313 1163-1167.

Cunha N, Rodrigues F, Curado F, Ilheu O, Cruz C, Naidenov P, Rascao MJ, Ganho J, Gomes I, Pereira $\mathrm{H}$, Real O, Figueiredo $\mathrm{P}$, Campos B \& Valido $\mathrm{F}$. Thyroglobulin detection in fine-needle aspirates of cervical lymph nodes: a technique for the diagnosis of metastatic differentiated thyroid cancer. Eur J Endocrinol 2007157 101107

Frasoldati A, Toschi E, Zini M, Flora M, Caroggio A, Dotti C \& Valcavi R. Role of thyroglobulin measurement in fine-needle aspiration biopsies of cervical lymph nodes in patients with differentiated thyroid cancer. Thyroid 19999 105-111.

Giovanella L, Ceriani L \& Suriano S. Lymph node thyroglobulin measurement in diagnosis of neck metastases of differentiated thyroid carcinoma. J Thyroid Res 20112011621839

Jeon SJ, Kim E, Park JS, Son KR, Baek JH, Kim YS, Park do J, Cho BY \& Na DG. Diagnostic benefit of thyroglobulin measurement in fine-needle aspiration for diagnosing metastatic cervical lymph nodes from papillary thyroid cancer: correlations with US features. Korean J Radiol 200910 106-111.

Kim DW, Jeon SJ \& Kim CG. Usefulness of thyroglobulin measurement in needle washouts of fineneedle aspiration biopsy for the diagnosis of cervical lymph node metastases from papillary thyroid cancer before thyroidectomy. Endocrine 2012.

Kim MJ, Kim EK, Kim BM, Kwak JY, Lee EJ, Park CS, Cheong WY \& Nam KH. Thyroglobulin measurement in fine-needle aspirate washouts: the criteria for neck node dissection for patients with thyroid cancer. Clin Endocrinol (Oxf) 200970 145-151.

Lee MJ, Ross DS, Mueller PR, Daniels GH, Dawson SL \& Simeone JF. Fine-needle biopsy of cervica lymph nodes in patients with thyroid cancer: a prospective comparison of cytopathologic and tissue marker analysis. Radiology 1993187 851-854.

Lee YH, Seo HS, Suh SI, Lee NJ, Kim JH, Seol HY, Lee JH, Kwon SY, Kim NH, Seo JA \& Yang KS, Cutoff value for needle washout thyroglobulin in athyrotropic patients. Laryngoscope 2010120 1120-1124.

Pacini F, Fugazzola L, Lippi F, Ceccarelli C, Centoni R, Miccoli P, Elisei R \& Pinchera A. Detection of thyroglobulin in fine needle aspirates of nonthyroidal neck masses: a clue to the diagnosis of metastatic differentiated thyroid cancer. J Clin Endocrinol Metab 199274 1401-1404.

Salmaslioglu A, Erbil Y, Citlak G, Ersoz F, Sari S, Olmez A, Tunaci M, Yilmazbayhan D, Colak N \& Ozarmagan $S$. Diagnostic value of thyroglobulin measurement in fine-needle aspiration biopsy for detecting metastatic lymph nodes in patients with papillary thyroid carcinoma. Langenbecks Arch Surg2011 396 77-81.

Sigstad E, Heilo A, Paus E, Holgersen K, Groholt KK, Jorgensen LH, Bogsrud TV, Berner A \& Bjoro T. The usefulness of detecting thyroglobulin in fine-needle aspirates from patients with neck lesions using a sensitive thyroglobulin assay. Diagn Cytopathol 200735 761-767.

Snozek CL, Chambers EP, Reading CC, Sebo TJ, Sistrunk JW, Singh RJ \& Grebe SK. Serum thyroglobulin, high-resolution ultrasound, and lymph node thyroglobulin in diagnosis of differentiated thyroid carcinoma nodal metastases. J Clin Endocrinol Metab 200792 4278-4281.

Sohn YM, Kim MJ, Kim EK \& Kwak JY. Diagnostic performance of thyroglobulin value in indeterminate range in fine needle aspiration washout fluid from lymph nodes of thyroid cancer. Yonsei Med J 201253 126131.

Zanella AB, Meyer EL, Balzan L, Silva AC, Camargo J, Migliavacca A, Guimaraes JR \& Maia AL. Thyroglobulin measurements in washout of fine needle aspirates in cervical lymph nodes for detection of papillary thyroid cancer metastases. Arq Bras Endocrinol Metabol 201054 550-554.
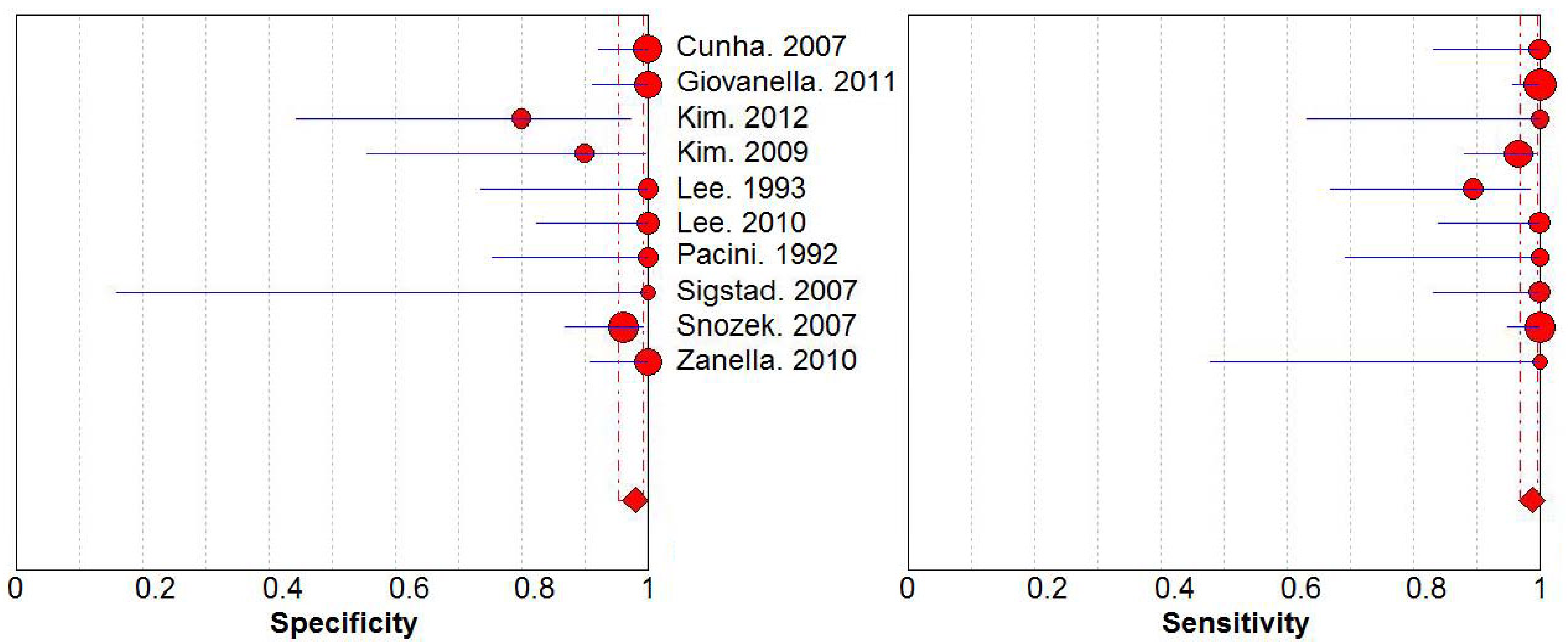

Figure 1: Forest plot of pooled sensitivity and specificity, including only 10 studies reporting data from patients during follow-up.

For specificity: heterogeneity chi-squared $=12.74$ (d.f. $=9$ ) $p=0.175$ For sensitivity: heterogeneity chi-squared $=15.19$ (d.f.= 9) $p=0.086$ (not significant heterogeneity between studies)

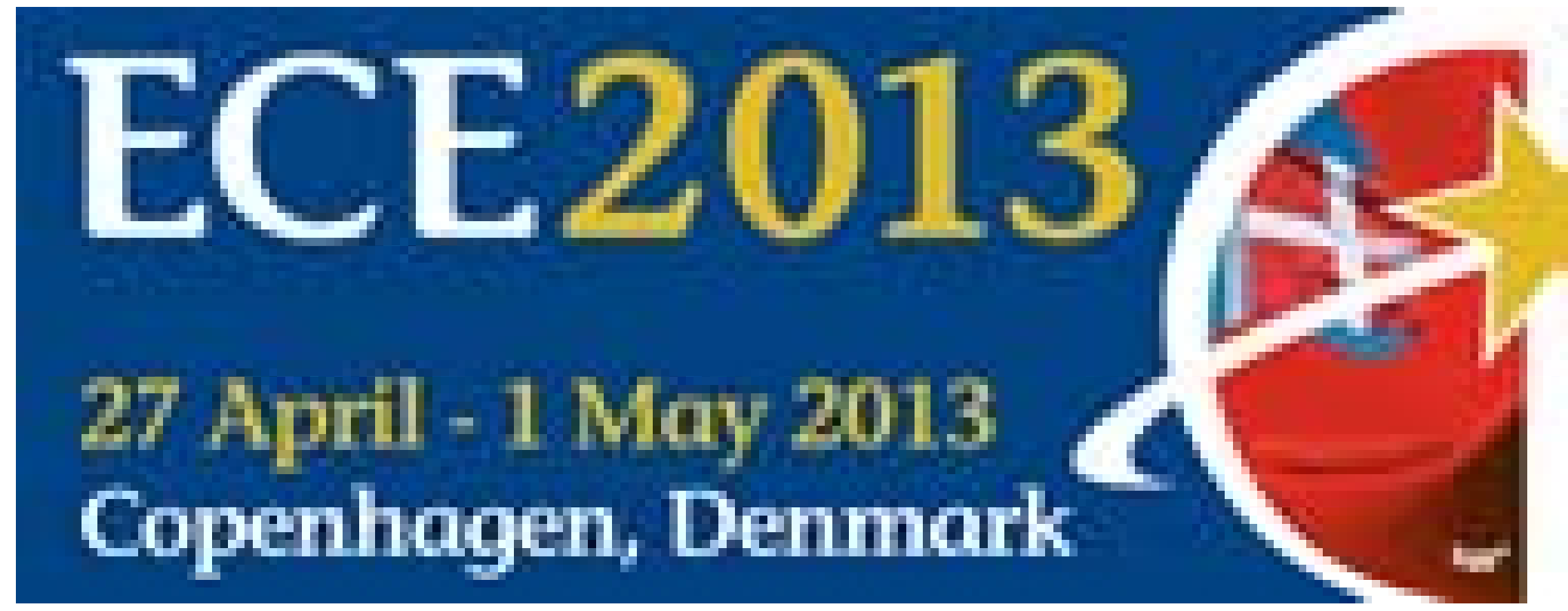

